\title{
Behavior, Satisfaction and Demand of Customers towards Healthy Breakfast Cereal
}

\begin{abstract}
This is an applied research which used descriptive social science research methodology. The research objective was to study behavior, satisfaction, and demand of customers towards the marketing mix on the Young puff rice and fruit breakfast cereal product of Ban Nam Om community enterprise.
\end{abstract}

Keywords: Young puff rice, breakfast cereal, community enterprise, marketing mix.

Publikacija yra taikomasis mokslinis tyrimas, kuriame pritaikoma apra omoji socialinių mokslų tyrimų metodologija. Tyrimo tikslas yra ištirti bendrijos „Ban Nam Om“ įmonès produktų: ankstyvụjų sluoksniuotų ryžių ir sausų vaisių pusryčių iš grūdų - vartotojų elgseną, pasitenkinimą ir vartotojų poreikiai marketingo komplekso atžvilgiu.

Raktiniai žodžiai: ankstyvieji sluoksniuoti ryžiai, vaisių pusryčiai iš grūdų, bendrijos įmonè, marketingo kompleksas.

\section{Introduction}

This research was supported by the Higher Education Research Promotion and National Research University Project of Thailand, Office of the Higher Education Commission, under the Food Product and Functional Food Research Cluster of Khon Kaen University as the project code FC 5.2.8 MS., under the research title "Behavior, Satisfaction and Demand of Customers towards Product Marketing and Packaging of Healthy Breakfast Cereal in the Level of
Thai Community and Commercial Product: A Case Analysis of Community Enterprise of Ban Nam Om, Nam Om, Kaset Wisai, Roi Et Province (as part of research project title "Product Marketing and Packaging of Healthy Breakfast Cereal in the Level of Thai Community and Commercial Product (Phase 1)").

Since nowadays urban way of life is fastpaced, it changes people's health behavior, especially workers and students who have to leave the house early in the morning, in order to get to work and school in time.

Ruchirat PATANATHABUTR - Assistant Professor and Ph.D.; Marketing; College of Graduate Study in Management (CGSM), Khon Kaen University (KKU), address: Instructor, 123 Sunthorn-Araya Arunanondchai Building, Mittraphap Road, Nai Muang District, Muang, Khon Kaen 40002 Thailand. Tel.: (6643) 362021 Fax: (6643) 362020. E-mail: pruchi@kku.ac.th. Scientific research areas: marketing, strategic management, SMEs. Tewaporn CHAIYAKAL - Master Degree, Marketing; College of Graduate Study in Management (CGSM), Khon Kaen University (KKU), address: Student, 123 Sunthorn-Araya Arunanondchai Building, Mittraphap Road, Nai Muang District, Muang, Khon Kaen 40002 Thailand. Tel.: (6643)362021 Fax: (6643) 362020. E-mail: tewapon_14@hotmail.com. Scientific research areas: marketing, strategic management, SMEs. 
Some people claim that skipping breakfast is how they can lose weight. They do not realize the importance of breakfast. As a result, they do not get enough energy from breakfast which is the most important meal of the day because breakfast marks a beginning point of daily energy supply, so that one can work or use one's brain normally (www.webmd.com, 2013). Therefore, breakfast products are important and the market still has room for new breakfast products if marketing improvement can meet consumers demand and behavior.

Thus, the study of product marketing and packaging of healthy breakfast cereal in the level of Thai community and commercial product is important for product distribution to consumers. To do so, it is important to consider behavior and demand towards the following five aspects of the healthy breakfast cereal marketing mix: product, packaging, price, distribution channels, and marketing promotion. The results were used to develop a product marketing strategic plan, production possibility and packaging design that meet customer demand, leading to transmission of product technology and marketing strategies to target entrepreneurs. To support the North-eastern community enterprise that have potential for increasing skills of managing community enterprise, analyses of external environment, that has direct and indirect effects on community enterprise, and studies on behavior, satisfaction, differences of satisfaction levels and consumer demand towards marketing mix can be used in product development to meet customer demand, to increase competitiveness and income as well as to improve quality of life of Ban Nam Om community enterprise members which was weakness in their marketing.
Research objectives. The research objectives were to study behavior of Young puff rice and fruit breakfast cereal's consumers, to study satisfaction and differences between consumers' satisfaction levels towards marketing mix of Young puff rice and fruit breakfast cereal of Ban Nam Om community enterprise, and to study the customer demand on marketing mix of Young puff rice and fruit breakfast cereal of Ban Nam Om community enterprise.

The aim. The aim was to suggest product marketing and packaging guidelines for Young puff rice and fruit breakfast cereal Ban Nam Om community enterprise.

The research method. This is an applied research using descriptive social science research methodology. Collected data were analyzed and presented (Triola, 1995) with descriptive statistics to explain frequency distribution, mean and difference of variables. Inferential statistics was utilized to describe relations between the data and hypotheses, while the method of inference is used to draw conclusions about the population (Salkind, 2003).

Variable declaration. Independent variables were functional food consumers in Muang District, Roi Et. Input factors were classified by gender, age, educational level, occupation, and average monthly income. Dependent variables were consumer satisfaction towards marketing mix of Young puff rice and fruit breakfast cereal of Ban Nam Om community enterprise, Kaset Wisai, Roi Et.

Scope of the study. The scope of this study was limited to behavior, satisfaction and demand of consumers who had tried Young puff rice and fruit breakfast cereal of Ban Nam Om community enterprise, Kaset Wisai, Roi Et. The product samples were distributed for tasting to measure their satisfaction and extra demand 
before completing the questionnaires. Participants were selected by using Taro Yamane's table, resulting in a total of 400 questionnaires (Pengsawat, 2008).

Product stipulation for the study. Entrepreneurs stipulated that 4 formulas of Young puff rice and fruit breakfast cereal were to be the products used in this study.

Methodology and instrument validation. The instruments were an entrepreneur interview and a customer questionnaire. They were examined by three experts (Pattiyathanee, 2005) - Mrs. Sangjan Pirun, the chairman of Ban Nam Om community enterprise, Assistant Professor Wichean Woraputporn, a food technology expert, and Asst. Prof. Rujirat Patanathabut, a management expert, to achieve the final value of the index of consistency (IOC) between 0.5 and 1 . The reliability of the questionnaire was examined by distributing 30 questionnaires to the consumers who had tried Young puff rice breakfast products before. After that, the reliability of the research tool was calculated with Cronbach's $\alpha$ (alpha) resulting in the correlation coefficient of 0.86 for the whole questionnaire and 0.7-0.9 which indicated a high correlation. When the same results occurred, it meant that the questionnaire was reliable and could be used in the research (Seesaad, 1995).

Data collection. Data was collected in a brainstorming session with the entrepreneurs. The products were selected for this study by interviewing the entrepreneurs to collect information about internal environmental factors in Ban Nam Om community enterprise. Secondary information was obtained from the Internet. This set of information was used to analyze external environmental factors of the business. 400 questionnaires were distributed to consumers, and the sample products were offered to the respondents before answering the questionnaire on the product's taste. The results were later used in the brainstorming session with the enterprise entrepreneurs to create a marketing strategic plan for the products.

Hypotheses. Five hypotheses were formed as follows:

(1) Consumers of different genders had no difference in satisfaction level towards marketing mix of Young puff rice and fruit breakfast cereal of Ban Nam Om community enterprise.

(2) Consumers of different ages had no difference in satisfaction level towards marketing mix of Young puff rice and fruit breakfast cereal of Ban Nam Om community enterprise.

(3) Consumers with different educational levels had no difference in satisfaction level towards marketing mix of Young puff rice and fruit breakfast cereal of Ban Nam Om community enterprise.

(4) Consumers of different occupations had no difference in satisfaction level towards marketing mix of Young puff rice and fruit breakfast cereal of Ban Nam Om community enterprise.

(5) Consumers with different ranges of average monthly income had no difference in satisfaction level towards marketing mix of Young puff rice and fruit breakfast cereal of Ban Nam Om community enterprise.

Decision making condition in the study. To decide whether to accept or reject Null hypothesis $\left(\mathrm{H}_{0}\right)$, a comparison of significant values was required. To accept Null hypothesis, computed significant value was 0.05 or greater. To reject Null hypothesis, computed significant value was less than 0.05 . 


\section{Literature review}

\section{Related concepts and theories}

(1) External environment is an analysis of external organizational factors that result in advantageous and disadvantageous impacts on the organization. Because these factors exist outside the organization, they are likely to change over time. The analysis can be divided into 2 issues. First, external environment that directly affects business includes suppliers, customers and competitors. Second, external environment that indirectly affects business consists of political, economic, social, technological and ecological factors (Sirinirundon, 2008).

(2) Internal environment analysis is composed of two parts as follows: (1) Functional management to achieve goal(s) is based on appropriateness, worthiness and resources, and it should be concretely explained. The accountability which is part of management to achieve objectives set by organizations comprises planning, organizing, leading and controlling; (2) Business management, whether aiming at production or service, is to respond to social demand to keep the organizations growing and to make profit. However, as the changing environment intensifies competition, all business organizations need to have effective administrative plans to achieve effectiveness and efficiency with proper investment capital that will enable them to be ready for competition. Therefore, it requires organizations with effectiveness and efficiency of human resources management, production management, marketing management, financial and accounting management, and economic management (Staff of Teachers of the Faculty of Management Science Suandusit Rajabhat University, 2005).
(3) Situational analysis: K. R. Andrews' "SWOT analysis" is used in marketing strategy, SWOT (also known as TOWS) Analysis originated in corporate strategy. The SWOT concept, if not the acronym, is the work of Kenneth R. Andrews who is credited with writing the text portion of the classic Business Policy: Text and Cases (Learned et al., 1965) (Kuester, 2012).

SWOT is a part of marketing process in marketing analysis - the analysis of controllable and uncontrollable environmental factors - which leads to marketing decision-making.

The controllable environmental factors are target, business resources and business marketing mix, all of which are internal environmental factors. The uncontrollable factors are external environmental factors, including economics, society, politics and technology. Furthermore, marketing environmental factors include customers, competitors, and retailers. Target market consideration and marketing strategy formulation must be considered based on both controllable and uncontrollable environmental factors as follows.

Strengths refer to a consideration of internal environmental factors of business which make products, components of marketing mix or business outstanding among other competitors.

Weaknesses refer to a consideration of drawbacks of products or business, consisting of 4 components of marketing mix.

Opportunities are chances from external micro- and macro-environmental factors.

Threats mean a consideration of disadvantages, limitations or obstacles of business resulted from external environmental factors (Roajsang, 2007). 
(4) Consumer behavior analysis. Consumer behavior is the study of individuals, groups or organizations and the processes they use to select, secure and dispose of products, services, experiences or ideas to satisfy needs and the impacts that these processes have on the consumer and society (Kuester, 2012). Customer behaviour study is based on consumer buying behaviour, with the customer playing the three distinct roles of user, payer and buyer. Research has shown that consumer behaviour is difficult to predict, even for experts in the field (Armstrong, 1991). The Consumer behavior analysis will help executives or proprietors improve efficiency in marketing planning and satisfy consumer demand. Stimuli of this analysis are: Who is the target market? Who participates in the buying? What does the consumer buy? When does the consumer buy it? Where does the consumer buy it? Why does the consumer buy it? And how does the consumer buy it? The answers to these questions can provide 7 sets of information or 7Os: occupants, roles of different organizations affecting buying decision, objects, occasions, outlets or channels, objectives and operations or buying process (Saereerat, 2007).

(5) Measurement of satisfaction levels refers to a survey on customers' feelings after buying products. The perception of working or product efficiency is compared with consumers' expectation of product and service. If products or services meet consumers' expectation, they will be satisfied. If the products or services are beyond their expectation, they will be impressed. Yet, if the products do not meet their expectation, they will feel dissatisfied (Serirat et al., 1998). A well-known measurement of satisfaction, called Likert scale, is widely used because it is easy to construct. One side of the scale represents "agree", and the other represents "disagree". The five given satisfactory choices for each question are strongly disagree, disagree, neutral, agree and strongly agree (Santisuk, 1993).

(6) Study of demand is to survey consumers' demand which influences their common action or behavior in society. It is clear that their behavior depends on the basic necessities of living and proper ongoing improvement of quality of life. Such behavior will change in accordance with marketing offers in particular societies (Tamjaruen, 1987).

(7) Study of marketing mix. The marketer E. Jerome McCarthy proposed a four Ps classification in 1960, which has since been used by marketers throughout the world (Kerin et al, 2001). The study of marketing mix is a study on products which satisfy target groups' demand with reasonable prices that convince customers to buy for their worthiness. Moreover, it studies product distribution corresponding to customers' buying behavior and facilitating the customers by persuading them to like the product and to possess appropriate purchase behavior (Wongmonta, 1999). The study also focuses on marketing tool provision corresponding to marketing goals of products and service (Kertsak Na Wangnoi et al., 2003). The marketing mix is often crucial when determining a product or brand's offering, and is often synonymous with the four Ps: product, price, place, and promotion (Needham, 1996). In this research, there are five components of marketing mix because of categorized packaging out of product studying as follows; (1) Product is seen as an item that satisfies what a consumer needs or wants. It is a tangible good or an intangible service (Kerin et al, 
2001). Product area concerns studies of design processes and product improvement influenced by the perception of consumer demand, the allocation of product tools, concept formation of products, selection of the best concept, stipulation of sub-system, detailed sketching, testing and prototype creation (Sasnan, 2003). (2) Packaging involves a study of package design and production or a method that makes the products similar to or different from one another in order to satisfy customer demand (Jitraktum, 2007). (3) Price indicates the value of products in the form of money. Price is consumers' capital paid in exchange with products or service. Customers compare product value with its price. If the value is higher than the price, the customer may decide to purchase the product. When setting a price, the marketer must be aware of the customer perceived value for the product. Three basic pricing strategies are: market skimming pricing, market penetration pricing and neutral pricing (Kerin et al, 2001). (4) Channels of distribution refer to providing the product at a place which is convenient for consumers to access (Kerin et al, 2001). A study of paths of product delivery from producers or retailers, or to customers, or to users, whether through middlemen or not, it is important to consider whether a particular channel is proper or whether it needs to be changed. (5) Marketing promotion is how business communicates with customers to inform customers of available product information and persuade them to believe that the products can satisfy their need. It also promotes events held by marketing dealers in order to receive customers' attentions with one or mixed activities depending on time and situation. Promotion comprises elements such as: advertising, public relations, personal selling and sales promotion (Kerin et al, 2001).

(8) Brainstorming is the use of thinking skills of members to together deliberate over particular matters. The results of brainstorming are used to plan the future actions. People who either dislike thinking or think individually may not perform well in this brainstorming activity (Kaewsri, 2001).

\section{Related concepts and research studies}

The breakfast cereal which is a food made from processed grains that are often eaten with the first meal of the day. Some companies promote their products for the health benefits from eating oat-based and high-fiber cereals. Cereals may be fortified with vitamins. Some cereals are made with high sugar content (wikipedia.org, 2013). The breakfast cereal industry has gross profit margins of 40-45\% (Lawrence, 2006), $90 \%$ penetration in some markets (Breakfast Cereals Market Report - Market Research Reports - Rsearch and Markets, 2008), steady and continued growth throughout its history (Breakfast Cereals: A Report on the Supply of Ready Cooked Breakfast Cereal Foods, 1973). Rice is the dominant cereal crop in many developing countries and is the staple food for more than half of the world's population. In several Asian countries, rice provides $50-80 \%$ of the energy intake of the poor. Because of the high per capita consumption of rice in these countries, increasing its nutritive value could have significant positive health outcomes for millions of people (International food policy research institute, 2006). The selected regions of the rice genome have been 
sequenced and shown to be collinear at the sequence level with limited regions of other cereal genomes. A large number of expressed gene sequences and molecular markers have accumulated in the public databases. Large insert clone libraries of the rice genome have been constructed, and rice has become an increasingly attractive candidate for whole genome sequencing (Goff, 1999).

In Thailand studying area, J. Seedaken (2010) found that the ratio of consumers - men to women - was 3:2. Most of the consumers were between the ages of 20 and 30, who were undergraduates and government officers. It also revealed that the customers independently made decision to buy the products. The customers mainly paid attention to the tastes and bought the product for themselves. Consumer demand towards marketing mix disclosed that they wanted tasty product sold at reasonable price and they expected to find the product in local shops. N. Wanichkittikul (2010) and A. Tanapongporn (2010) found that the ratio of consumers was 1:1 (female to male) and the ratio of approximately 5:4 (female to male), respectively. They were undergraduates with a monthly average income of less than 10,000 Baht. They bought the breakfast for themselves during festive periods, and they were informed of the product by friends or acquaintances. They were likely to buy the product in exhibitions and festive events. R. Peudjuntuk's (2010) work showed that the main reasons for not consuming the product were because of the limited distribution channels and its unsatisfied taste. They influenced themselves to purchase the product. They bought the product when they found it convenient to do so. An average cost of each purchase was between 10 and 30 Baht. Consumer demand towards the marketing mix was revealed that improvement was needed in terms of taste, quality package, delivery service, reasonable price, product quality, channels of distribution and marketing promotion. W. Woraputporn (2007) found that all types of Young puff rice breakfast products received high acceptance. According to the analysis of consumers' sense satisfaction, 100 people in Khon Kaen and 103 in Roi Et were most satisfied with Young puff rice and fruit breakfast cereal. This could be applied to the study on behavior, and demand of customers towards Young puff rice breakfast and other Young puff rice products. The increase in a variety of products provided customers with alternatives, leading to customers' higher satisfaction level, higher product value, and product development. The product should be stored in two types of packages, including KOP plastic bags and aluminum bags with oxygen absorbers inside to prevent the product from creating rancid smell and to maintain its crispiness. There should be a label containing the product information on a paper box to attract consumers. Also, the customers were most likely to buy Young puff rice and fruit breakfast cereal. They preferred the product to be stored in aluminum bags to plastic bags and wanted the product to be packed in a box with a handle. And P. Chaimanat and P. Rackchamroon (2011) found that the country of origin does not affect much in consumers' buying decision in term of low-involvement products. Also country of origin showed that can influence consumer first purchasing activity. When consumers have more knowledge or experience other cues such as price and taste have definitely effects in their buying decision more than country of origin factors. 


\section{Information about Ban Nam Om community enterprise}

The community enterprise is a group of agriculturist housewives in Ban Nam Om, established on 25 August 1992. Its office is located at $152 \mathrm{Moo} 7, \mathrm{Nam} \mathrm{Om}$ District, Kaset Wisai, Roi Et. There are currently 190 members, and the community enterprise raises funds by selling a share at 500 Baht. The main group is "Young puff rice Production". The enterprise aims at increasing household income, solving unemployment and immigration problems and increasing value of agricultural products.

The SWOT analysis of the community enterprise management in this study indicated the strengths, weaknesses, opportunities and threats as follows.

\section{Strengths}

- Flat administration allowed fast command and communication.

- Group meetings were arranged monthly to exchange information and seek improvement solutions.

- Members of Ban Nam Om community enterprise received welfare, dividend and medical fee.

- Production capacity was flexible.

- Production staff was experienced and skillful.

- The product received certified symbols issued by the Food and Drug Administration and OTOP 5 Stars.

- There was a variety to Young puff rice products and they were tasty.

- The brand logo was created to be remembered and recognized.

- The products were with high profitability.

- The business has high liquidity and short-term debt paying ability.
- The income that the members received from the enterprise's products was 5 times as much the income earned from their main jobs.

Weaknesses

- Chairman was the only person who made decision and operated the enterprise.

- There was no assignment of roles and responsibilities.

- Parts of production equipment were old, out of order, and outdated.

- Quality control was not strictly practiced.

- Channels of distribution and public relations were limited.

- Ban Nam Om enterprise lacked communication technology knowledge that could be used to advertise marketing promotion.

- Investment fund was not used effectively.

The results of external environmental analysis of Ban Nam Om community enterprise were as follows;

Opportunities

- Customers were likely to consume more healthy food.

- There was no competitor in the market of Young puff rice breakfast products.

- Government sector supported the improvement of production standard and promoted efficient rice processing as well as agricultural production.

- Government sector distributed authority and fund the personnel working in the business.

- Communication technology was currently convenient and fast.

- Roi Et was a suitable area to grow fine rice and Tunggula jasmine rice.

- $\quad$ Roi Et had Young puff rice eating culture. 
- Government sector helped promoting the products in exhibitions and trade fairs.

Threats

- Commercial competitors became more interested in functional breakfast because of the current health care trend.

- There was imitation of original products.

- The cost of ingredients increased.

- Customers hardly knew Ban Nam Om community enterprise.

- Natural disasters and global warming resulted in the decrease in final products.

\section{Conceptual framework}

This study classified customers of the consumers of Young puff rice breakfast product by gender, age, educational level, occupation and average monthly income rate, while the entrepreneur of Ban Nam Om community enterprise, Kaset Wisai, Roi Et, were the input factors in this study. Customer questionnaires and entrepreneur interview form were design based on customer behavior theories, including satisfaction theory, marketing mix theory, product and packaging design theory. They were used to discuss related studies and to study the management of Ban Nam Om community enterprise, Muang District, Roi Et.

\section{Results of the study}

The results were presented in 5 following parts.

(1) General information of functional food consumers. General information of the consumers in Muang District, Roi Et, show that most consumers were females between the ages of 20-30 years and 30 to 40 years, respectively, with bachelor's degree, working as government officers, state enterprise employees and earning average monthly income of 5,000-10,000 Baht and 10,000-20,000 Baht, respectively.

(2) Behavior of Young puff rice and fruit breakfast cereal customers. According to the results related to consumption behavior of the customers of healthy breakfast in Muang District, Roi Et, a majority of consumers independently made their decision to buy the product and they influenced themselves to do so. Other healthy breakfast products they bought apart from the product of Ban Nam Om community enterprise were similar breakfast products of Nestle. The customers most often bought Young puff rice and fruit breakfast cereal and Young puff rice and grain breakfast cereal was the second most often purchased product. They usually ate the cereal with milk and sometimes ate it without milk as crispy snack. They most often ate healthy food in the morning at home. They also ate it in the evening at home. Occasionally, they ate it again when it was convenient for them. The consumption frequency was not regular. Some ate it once or twice a week. Most customers obtained information about the product from exhibition and trade fairs. The channels of distribution were exhibitions and shops, respectively. The reason they bought the product was due to its good taste and its health benefits, respectively. Also, the reason they bought Nestle's products was that it was healthy and tasty, respectively. They bought the functional breakfast of Celox as it was good for health and delicious. Besides, they purchased similar products of Doné for its deliciousness and health benefits. All in all, consumers' objective of buying Young puff 
rice breakfast products was for its health benefits and for their convenience. Most consumers bought the product by themselves and spent average amount of 30-60 Baht and 15-30 Baht on each purchase.

(3) Satisfaction level of customers towards marketing mix of Young puff rice and fruit breakfast cereal of Ban Nam Om community enterprise. The overall customer satisfaction towards the marketing mix of breakfast product was high. The follows items were ranked from high level of satisfaction to low level of satisfaction: product sanitation, delicious taste, appetizing colors, nutritional value easy storage options and long-term preservation. The package received high satisfaction for the beautiful fonts, fascinating and durable materials, colorful graphics and detailed information on package. Also, the customers had neutral satisfaction towards material quality, modern design, beauty and handiness and consumption convenience. The customers had neutral satisfaction towards the comment that the current price was suitable for the product quality. They also had moderate satisfaction towards channels of distribution. The product of the community enterprise could be bought easily. The satisfaction of the marketing promotion was moderate. There was a public relations sector that could be used to contact the group and to advertise marketing promotions, such as a demonstration of how to make Young puff rice, discounts and availability of product samples for tasting.

(4) Differences between customer Satisfaction levels towards the Marketing Mix of Young puff rice and fruit breakfast cereal classified by gender, age, educational levels, occupations, and average income rate. Levels of customer satisfaction towards the marketing mix of the product classified by gender, age, educational level, occupation, and average monthly income indicated no statistically significant difference at 0.05 . The results also showed that satisfaction level of the consumers of different education levels had statistically significant difference at 0.05. In particular, the customers with bachelor's degree were more satisfied with the marketing mix than those with secondary education.

(5) Extra demand of customers towards marketing mix of Young puff rice and fruit breakfast cereal of Ban Nam Om community enterprise. In terms of product quality, a majority of consumers wanted the product to possess OTOP 5 Stars. They would like to store the product for 3-6 months. Colors of the food should be natural. Its taste should be sweeter and an extra ingredient for this food should be dried pineapple.

As for the package, most consumers wanted the entrepreneurs to use environmentally friendly materials with specification of nutritional value. The product should be put in plastic bowls. Fonts on package should reveal Thai identity, styles and colors. The product should be packed in boxes.

Concerning the product price, most of the consumers expected to see a variety of packages for Young puff rice and fruit breakfast cereal sold at 10 Baht (50 g), 15 Baht (50 g), and 25 Baht (50 g).

Regarding channels of distribution, most consumers had high demand on the product availability in malls, convenient stores and grocery stores.

Concerning the marketing promotion, the customers would like to see more advertisements and demonstrations of how to cook Young puff rice in exhibitions and trade fairs. 


\section{Conclusions}

A brainstorming session between the researcher and the entrepreneurs about consumers' behavior, satisfaction, demand and the SWOT analysis resulted in a marketing strategic guideline for Young puff rice breakfast product.

Marketing suggestions for the product and package of this functional breakfast from Young puff rice are listed as follows.

In the level of commercial product, the product should possess certified symbols issued by OTOP 5 Stars and the Food and Drug Administration. Also, for the product should last 3-6 months as the longest period without creating rancid smell. The colors should be natural. The taste should be sweeter, while fine dried fruit, such as pineapples or other seasonable fruit, can also be added. In addition, the amount of Khao Tok should be reduced.

In the level of community product, the package should be made of environmentally friendly materials, such as paper boxes. Thai fonts should be printed on Thai background image and from the health benefits of Young puff rice and the manufacture date should also be on the sides of the box.

In the level of commercial product, the design and color of the packages should be adjusted. There can be beautiful food images, nutrition facts, health benefits and the manufacture date on the sides on the box. Moreover, Thai patterns and Thai alphabets should be written on the box to show Thai identity. The container should be a plastic bowl which is handy and convenient to eat with milk. To make the packages for souvenir purposes on any occasions, the products can be put in a basket or a box with a handle.
In the level of community product, the price and ingredients should be reduced.

In the level of commercial product, the price should be raised and the volume of ingredients should be increased.

Channels of distribution should be increased. For example, the products should be offered in cooperative shops, grocery stores, convenient stores and malls as well as community area and places for exercise - fitness centers, health parks. In addition, a website should be created to provide product information and contact information, such as phone number and address.

Marketing promotion should tell consumers the health benefits of the food product. There should be a direct sale in a form of gifts and souvenirs for private companies, businessmen and government officers on special occasions. Advertisements and demonstration of how to cook Young puff rice as well as free sample products should be available in exhibitions and trade fairs. The advertisements should also be posted on the Internet.

\section{Related research discussion}

There are some issues corresponding to related studies. Most of the consumers were females with bachelor's degree, earning average income of 5,000-10,000 Baht per month. It agreed with N. Wanichkittikul's (2010) and A. Tanapongporn's (2010) research findings. In terms of consumer behavior, buyers influenced themselves to make purchase decision. On the subject of product, it was healthy and tasty. For marketing promotion, the customers tasted the product before making purchase, corresponding to J. Seedaken's (2010) and R. Peudjuntuk's (2010) research results. In 
addition, customers most often decided to buy Young puff rice and fruit breakfast cereal, as also found in W. Woraputtorn's (2007) research.

\section{Suggestions}

The results of this study can be used in the following studies;

(1) Product and Package Development Guidelines for Healthy Breakfast Cereal in the Level of Thai Community and Commercial Product: A Case Analysis of Community Enterprise of Ban Nam Om, Kaset Wisai, Roi Et Province

(2) Feasibility Study on Investment Following the Product and Package Development Guidelines of Healthy Breakfast Cereal in the Level of Thai Community and Commercial Product: A Case study of Community Enterprise of Ban Nam Om, Nam Om, Kaset Wisai, Roi Et Province.

\section{Acknowledgement}

This research was supported by the Higher Education Research Promotion and National Research University Project of Thailand, Office of the Higher Education Commission, through the Food and Functional Food Research Cluster of Khon Kaen University. It is a research in a research cluster of Food Product and Functional Breakfast in the Northeastern Region, Project code FC 5.2.8 MS, under the title "Behavior, Satisfaction and Demand of Customers towards Product Marketing and Packaging of Healthy Breakfast Cereal in the Level of Thai Community and Commercial Product: A Case Analysis of Community Enterprise of Ban Nam Om, Nam Om, Kaset Wisai, Roi Et Province (as part of Research Project Title "Product Marketing and Packaging of Healthy Breakfast Cereal in the Level of Thai Community and Commercial Product (Phase 1)")".

\section{References}

1. "Breakfast Cereals Market Report - Market Research Reports - Research and Markets” (2008). Key Note Publications Ltd. Internet access: < http://en.wikipedia.org/wiki/Breakfast_cereal>, [accessed May 13, 2013].

2. "Breakfast Cereals: A Report on the Supply of Ready Cooked Breakfast Cereal Foods" (1973). The Monopolies Comission, Internet access: < http://en.wikipedia.org/wiki/Breakfast_cereal $>$, [accessed May 13, 2013].

3. Armstrong, J. S. (1991). "Prediction of Consumer Behavior by Experts and Novices". Journal of Consumer Research (Journal of Consumer Research Inc.). 18: 251-256.

4. Breakfast cereal. Internet access: < http:// en.wikipedia.org/wiki/Breakfast_cereal $>, \quad$ [accessed May 13, 2013].
5. Breakfast Is the Most Important. Internet access: <http://www.webmd.com/food-recipes/mostimportant-meal $>$, [accessed May 10, 2013].

6. Chaimanat, P., Rackchamroon, P. (2011). Influences of country of origin in Thai consumers' buying decision toward beer purchasing. Internet access: < http://www.essays.se /essay/ a0d11ed897/>, [accessed May 13, 2013].

7. Goff, S. A. (1999). Rice as a model for cereal genomics. Internet access: <http://www. researchgate .net/publication/12976886_Rice_ as_a_model_for_cereal_genomics $>$, [accessed May 10, 2013]. Current Opinion in Plant Biology (impact factor: 9.27). 05/1999; 2(2):86-9. doi: 10.1016/S1369-5266(99)80018-1.

8. International food policy research institute. (2006). Biofortified rice. Internet access: < http:// www. ifpri.org/>, [accessed May 13, 2013]. 
9. Jitraktum, N. (2007). Product and Price Policies. Bangkok: Phappim Press.

10. Kaewsri, P. (2001). Techniques of Brainstorming. Internet access: <http://www.moe.go.th/wijai/ brainstroming.htm $>$, [accessed June 28, 2554].

11. Kerin, R. A., Hartley, S. W., Rudelius, W. (2001). Marketing. The Core. 4th Edition, McGraw Hill Publishing.

12. Kertsak Na Wangnoi, C. et al. (2003). Principles of Marketing. Nakhon Ratchasima: Nakhon Ratchasima Rajabhat University.

13. Kuester, S. (2012). MKT 301: Strategic Marketing \& Marketing in Specific Industry Contexts, University of Mannheim, p. 110.

14. Lawrence, F. (2006). "How constipation cure became huge business". The Guardian (London). Internet access: < http://en.wikipedia.org/wiki/ Breakfast_cereal>, [accessed May 13, 2013].

15. Needham, D. (1996). Business for Higher Awards. Oxford, England: Heinemann.

16. Pattiyathanee, S. (2005). Foundation of Educational Research. Mahasarakarm: Press of the Faculty of Education, Mahasarakarm University.

17. Pengsawat, W. (2008). Research Methodology. Bangkok: Suwiriyasan.

18. Peudjuntuk, R. (2010). A Study of Development Guidelines of Marketing of Breakfast Products from Young puff rice Outside Muang District in Khon Kaen. (Master's Independent Study). Khon Kaen University: Khon Kaen.

19. Roajsang, S. (2007). Marketing Management. Bangkok: Arun Publishing.

20. Saereerat, S. (2007). Consumer Behavior. Bangkok: Theera Film and Cytex.

21. Salkind, N. J. (2003). Exploring Research. (5th ed.). Upper Saddle River, N. J.: Pearson Prentice Hall.

22. Santisuk, S. (1993). Research Methodology in Social Sciences: Principle of Building Knowledge to Measure Research Process, Data Analysis and Report Writing. Khon Kaen: Department of Sociology and Anthropology, Faculty of Humani- ties and Social Sciences, Khon Kaen University.

23. Sasnan, M. (2003). Product Design. Bangkok: TPA Publishing.

24. Seedaken, J. (2010). Improvement of Marketing of Breakfast Products and Snack from Young puff rice in Khon Kaen Municipality. (Master's Independent Study). Khon Kaen University: Khon Kaen.

25. Seesaad, B. (1995). Statistics of Research (2nd ed.). Bangkok: Suwiriyasan.

26. Serirat, S., Luksitanon, P., Serirat, S., Patawa, O. (1998). Strategies of Marketing, Administration and Case Studies. Bangkok: Teera Flim and Citex.

27. Sirinirundon, S. (2008). Analysis of Business Environment. Bangkok: $\mathrm{C} \& \mathrm{~N}$.

28. Staff of Teachers of the Faculty of Management Science Suandusit Rajabhat University. (2005). Basic Knowledge of Business Transaction. Bangkok: The Bookstore of Suandusit Rajabhat University.

29. Tamjaruen, Y. (1987). Consumers' Behavior. Bangkok: Sribun Industry Press.

30. Tanapongporn, A. (2010). A Study of Development Guidelines of Marketing of Breakfast Products from Young puff rice in Latyaow, Jatujuk, Bangkok. (Master's Independent Study). Khon Kaen University: Khon Kaen.

31. Triola, M. F. (1995). Elementary Statistics. (6th ed.). Redwood City, CA: Addison-Wesley.

32. Wanichkittikul, N. (2010). A Study of Development Guidelines of Marketing of Breakfast Products from Young puff rice in Roi Et. (Master's Independent Study). Khon Kaen University: Khon Kaen.

33. Wongmonta, S. (1999). Strategies of Marketing and Marketing Planning. Bangkok: Teera Flim and Citex.

34. Woraputporn, W. (2007). The Production and Development of Young puff rice Breakfast. Internet access: <http://ora.kku.ac.th/res_kku/ Abstract/Abstractview.asp?>, [accessed April 18, 2010]. 
Ruchirat PATANATHABUTR, Tewaporn CHAIYAKAL

\section{VARTOTOJŲ ELGSENA, PASITENKINIMAS IR POREIKIAI SVEIKŲ GRŪDINIŲ PUSRYČIŲ ATŽVILGIU}

\section{S a n tra u a}

Publikacija yra taikomasis mokslinis tyrimas, kuriame pritaikoma aprašomoji socialinių mokslų tyrimų metodologija. Tyrimo tikslas - ištirti bendrijos „Ban Nam Om“ i̇monès produktų: ankstyvųjų sluoksniuotų ryžių ir sausų vaisių pusryčių iš grūdų - vartotojų elgesị, pasitenkinimą ir vartotojų poreikiai marketingo komplekso atžvilgiu bei pateikti pasiūlymus dèl produktų marketingo ir pakuotès.

Atliktas tyrimas parodé, jog didžioji vartotojų dalis yra 20 - 30 metų amžiaus moterys, turinčios bakalauro laipsnị ir dirbančios valstybės tarnautojomis bei gaunančios vidutiniškai nuo 5,000 iki 10,000 Baht pajamų per mènesį. Vartotojai nepriklausomai apsisprende pirkti produktus. Jie nusprende pirkti ankstyvųjų sluoksniuotų ryžius bei sausus vaisių pusryčius iš grūdų ir vartoti su pienu rytais namuose. Su produktais vartotojai susipažino ir gavo informacijos parodose ir mugèse. Kiekvieno pirkinio vidutine kaina buvo 30 - 60 Baht. Taipogi, vartotojai labai patenkinti marketingo kompleksu. Skirtingų amžiaus grupių, lyčių, profesijų ir pajamų vartotojų pasitenkinimo lygis vienodas. Nors tarp skirtingo išsilavinimo vartotojų buvo statistiškai reikšmingų skirtumų 0,05. Be to, rezultatai taip pat parodė, kad pagal marketingo koncepciją, jie pageidautų, jog bendrijos „Ban Nam Om“ imonè butų sertifikuota OTOP 5 Žvaigždžių simboliu.

Marketingo pasiūlymai skirti ankstyvųjų sluoksniuotų ryžių ir sausų vaisių pusryčių iš grūdų produktams ir pakuotei pateikiami žemiau.

Kaip komercinis produktas, produktas turètų turèti patvirtintus OTOP 5 Žvaigždžių simbolio ir Maisto bei vaistų administracijos ženklinimus. Be to, produkto ilgiausias galiojimo laikas turètų būti 3 - 6 mènesiai, neskleidžiant aitraus kvapo. Spalvos tūrètų būti natūralios. Skonis turètų būti saldesnis, galètų būti pridèta daugiau džiovintų vaisių, tokių kaip ananasai ar kiti sezoniniai vaisiai. Be to, Khao Tok kiekis turètų būti sumažintas.

Kaip bendruomenèje vartojamas produktas, ịpakavimas turètų būti pagamintas iš aplinkai ne- kenksmingų medžiagų, pavyzdžiui, popierinių dèžių. Ant pakuotès turètų būti Thai šriftai turi būti atspausdinti ant Thai paveikslèlio fono. Pagaminimo data taip pat turètų būti nurodyta ant dèžès šonų.

Taip pat, komercinio produkto atveju, pakuočių dizainas ir spalvos galètų būti suderintos. Tokiu atveju gali būti panaudojami vaizdūs maisto paveikslèliai, pateikiami mitybos faktai bei nauda sveikatai ir pagaminimo data ant pakuočių šonų. Be to, siekiant parodyti Thai identiškumą, Thai šriftai ir Thai raidynai turètų būti nurodyti ant děžutès. Gaminio tara privalo būti plastiko dubuo, kuris yra lengvai ir patogiai pritaikomas valgant su pienu. Siekiant gamini pritaikyti kaip suvenyrą ar pateikti kitomis progomis, produktai gali būti supakuojami ¡̇ krepšius ar dèžes su rankenomis.

Kaip bendruomeneje vartojamas produktas, kainos ir ingredientai turètų būti sumažinti. Kaip komerciniam produktui, kaina bei sudedamųjų dalių kiekis turi būti padidintas.

Turètų būti naudojama daugiau platinimo kanalų. Pavyzdžiui, produktai galètų būti siūlomi mažose parduotuvèse, bakalejos parduotuvèse, didelèse parduotuvèse ir prekybos centruose, taip pat bendruomenès erdveje ir sporto centruose, sveikatos parkuose. Be to, siekiant suteikti informacijos apie produktą ir kontaktinę informaciją, pavyzdžiui, telefono numerị ir adresą, turi būti sukurta internetinè svetainè. Rinkodaros skatinimo srityje, klientai turètų būti informuojami apie maisto produkto naudą sveikatai.

Marketingo rèmimas turètų suteikti vartotojams informacijos apie produkto privalumus sveikatai. Tai galètų būti tiesioginis pardavimas, dovanų ir suvenyrų, skirtų privačių ịmonių, verslininkų ir valdžios ịstaigų atstovų ypatingomis progomis forma. Reklama ir demonstravimas kaip pagaminti ankstyvųjų sluoksniuotų ryžius ir sausus vaisių pusryčius iš grūdų, taip pat ir nemokami produktų mėginiai, galètų būti pateikiami parodose ir mugèse. Reklama taip pat turètų būti skelbiama internete. 